\title{
INTERACTION BETWEEN EDUCATIONAL INSTITUTIONS WITH BUSINESS COMMUNITY
}

\author{
T. Romashkin 1
}

DOI: http://doi.org/10.15350/L_21/2/08

\begin{abstract}
The article is devoted to analysis of the types of interaction of universities and business structures. At the present time, modern society creates demand for high quality of higher professional entities. Highlighted the benefits of this interaction.
\end{abstract}

Keywords: Institute of education, the business community, modernization.

В условиях современной экономики система образования является одной из главных отраслей социально-экономической сферы.

Модернизация образования со стороны государства направлена на достижение таких целей улучшения качества образовательных услуг, как приведение содержания и качества образования в соответствие с современными потребностями общества, государства, экономики, науки, культуры и отдемьной мичности, повышение доступности качественного образования, а также обеспечение конкурентоспособности регионального рынка образовательных услуг.

Известно, что совершенствование системы российского образования не останавцивалось с начала XX в., но, как известно, прогрессивное развитие современного общества и его потребности стремятся вперед. Момодежь несет с собой качественно новые знания и навыки, используя современные технологии и имея представление, какие компетенции могут быть получены за рубежом и каков уровень образования в международном образовательном пространстве.

Перед российскими вузами стоит множество вызовов, и успех предприятия, осуществляющего инновационную деятельность, способствует подъему социального статуса научной деятельности, привлечению в науку новых молодых кадров, повышению внутренней мотивации исследоватемей [1].

Из собственного опыта, следует отметить, что желание заниматься научной деятельностью зависит от наглядного примера успешных предпринимателей и руководителей предприятий. Примеры отражают взаимосвязь и сочетание научной и предпринимательской деятельности.

Но, важна и обратная зависимость бизнеса от науки, а именно бизнес разработки акцентируют внимание и опираются на исследования ученых высших учебных заведений, различных организаций (отраслевых, научных, исследовательских и т.д.).

Также важна кадровая составцяющая бизнеса, всем нужны высокопрофессиональные кадры, которые выращивают университеты, и биз-

${ }^{1}$ Timur Romashkin, Candidate of Economic Sciences, Associate Professor, Saratov national research State University named after N.G. Chernyshevsky, Saratov, Russia. 
нес-структуры отправляют свой кадровый состав на повышение квалификации в области инноваций, технологического и научного менеджмента.

Важна именно подготовка специалистов, необходимых экономике и полагаем, что мы этого сможем достичь, при тесном взаимодействии учебных заведений и бизнес-структур. Своего рода необходимо достичь синергетического эффекта.

Данная когерентность институтов позволит определить приоритетные направления деятельности вуза и реализовать стратегическое развитие бизнеса. Есть наглядные примеры данной когерентности, где отсутствует разрыв теории с практикой, это так называемые фирмы-партнеры.

Например, всем известная студенческая практика. Это традиционный способ взаимодействия, который занимает мидирующие позиции. Схема выгодна как студенту, который может ознакомиться с данным видом работы и в дальнейшем продолжить сотрудничать, так и работодателю, который имеет возможность увидеть подготавливаемых специаАистов в конкретной работе.

Далее, стоит отметить и другой тип взаимодействия - создание эндаументов (целевых капиталов) ведущих университетов.

Бизнес-структуры направляют финансовые средства в университет, который вкладывает их в акции или ценные бумаги и расходует полученные проценты по своему усмотрению. Таким образом, капитал бизнес-структур работает на будущее, составляя постоянную подпитку университету.

Когерентность высших учебных заведений и бизнес-сообществ так же происходит согласно целевым программам, обучению в корпоративных университетах и т.д. То есть университет осуществляет индивидуамьный заказ, получив его от работодателя.

Выдемим преимущества данного взаимодействия:

1) количество трудоустроенных выпускников конкретного вуза;

2) количество долгосрочных согмашений сотрудничества;

3) наличие вспомогательных источников финансирования и иных путей восполнения затрат на содержание высшего учебного заведения;

4) слаженность работы исследовательских проектов и образовательных программ, а также бизнес-структур;

5) построение и усовершенствование результативных экономических структур малого наукоемкого бизнеса;

6) построение базовых учебно-научно-производственных центров обеспечения программ и технологий подготовки молодых кадров;

7) модификация учебного процесса и усовершенствование инновационных технологий в образовании, науке и бизнесе.

Ядро данной инфраструктуры в основном составцяют технопарки и бизнес-инкубаторы, основная цель которых - объединить всех заинтересованных миц инвестиционно-инновационной политики для повышения эффективности. В большей мере сферой деятельности таких организаций является поддержка малого предпринимательства, а не инновационных предприятий. Но, как нам известно, предприниматели (малый бизнес) обладают наибольшей инновационной активностью и, следовательно, дают рынку значительный объем инновационных проектов и готовых инновационных продуктов. 
Важно сказать, что именно акцентируя внимание на университетах, а именно на усилиях молодежи, мы сможем построить совершенно новый тип экономики.

Поэтому, считаем, что перед Россией в целом, стоят следующие задачи:

1) Это перейти на инновационный путь развития, объединив трех основных субъектов инновационного рынка - бизнеса, образования и науки, то есть некое усиление функционирования институциональной спирали, а также подготовить высококвалифицированные кадры дмя инновационной сферы.

2) Необходима комплексная работа в сфере развития инфраструктуры, где особую ценность в этом диалоге имеет опыт и мнение практических специалистов, руководителей предприятий, финансовых организаций, а также способность анализировать успехи, которые удалось достичь тем или иным субъектам инновационной деятельности.

3) Далее, важно сформировать эффективную инновационную среду, от уровня развития которой будут зависеть скорость и результативность проводимых преобразований в стране [2, с. 67-72].

References:

[1] Ромашкин Т.В., Фимушкина А.А. Государственная поддержка малого бизнеса: миф или реальность?.Известия Саратовского университета. Новая серия. Серия: Экономика. Управление. Право. Выпуск 2. Научный журнал. 2016. Том 16.

[2] Устинова Н.Г. Анализ инновационной среды в России. Наука и общество. 2011. № 3. C. 67-72. 